\title{
Contribution to the determination of the elements of photovoltaic panel (PV) equivalent electric model. Application in the maximal power point (MPP) available analytical expression
}

\author{
V. Autier ${ }^{1}$, V. Molcrette ${ }^{2}$ and H. Roisse ${ }^{1}$ \\ ${ }^{1}$ Laboratoire Systèmes Electrotechniques et Environnement \\ L.S.E.E., Faculté des Sciences Appliquées \\ Technoparc Futura, 62400 Béthune (France) \\ Phone : (33)321-637-215, fax: (33)321-637-211, e-mail: vincent.autier@fsa.univ-artois.fr \\ ${ }^{2}$ University of Artois - Béthune France
}

\begin{abstract}
The authors present a method of determination of the parameters of the model 1-diode of the electrical equivalent circuit of a Photovoltaic module (PV) deduced from experimental characteristics. They establish from the electrical equivalent circuit an analytical expression of the maximum power point (called MPP). The influence of the temperature is taken into account in the form of an empirical coefficient. The later is calculated from the variation of the open circuit voltage $\left(V_{O C}\right)$.

A comparison between the analytical and experimental results is given for two kinds of amorphous silicium panel.
\end{abstract}

Keys words : I-V characteristic, 1-diode model, MPP, PV panel.

\section{Introduction}

The majority of simulations of the working point of the PV module are obtained from the electrical equivalent circuit shown in figure $n^{\circ} 3$. The knowledge of the electrical parameters is essential to predetermine the behaviour of the panels subjected to various irradiation and temperature. However, the manufacturers only give the external PV characteristics and give less information about these parameters. The authors present a simplified graphical method of determination of these parameters.

The manufacturing processes induce disparity in the I-V characteristic. This fact it is possible to find an optimal association of PV modules. However, the expression of the power is implicit and can be only obtained by numerical resolution [1] or iterative. So, it is quite difficult to establish the rules of association of PV modules. The authors show that an approximate analytical expression of the maximum power can be deduced from the equivalent electrical circuit. The expression introduces two remarkable factors such as the open circuit voltage $\left(\mathrm{V}_{\mathrm{OC}}\right)$ and the short-circuit current $\left(\mathrm{I}_{\mathrm{SC}}\right)$ and also correction factors in order to take into account the various imperfections of the solar cells.

\section{Equivalent electrical circuit of the PV module}

A PV module is an association made of $\mathrm{N}_{\mathrm{S}}$ photodiodes connected in series to increase the output voltage and $\mathrm{N}_{\mathrm{P}}$ identical node to increase the available delivered electrical power.

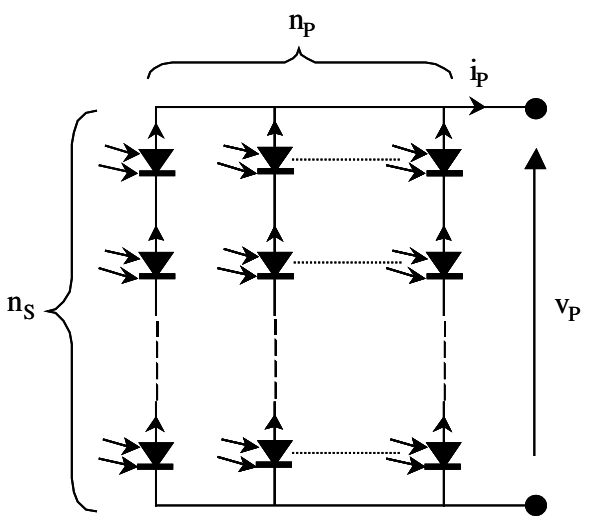

Fig. 1 : Classical configuration of a PV module

In the photovoltaic operating mode, the PV module works like a generator. The Fig 2 shows a traditional form of the $\mathrm{I}-\mathrm{V}$ characteristic. 


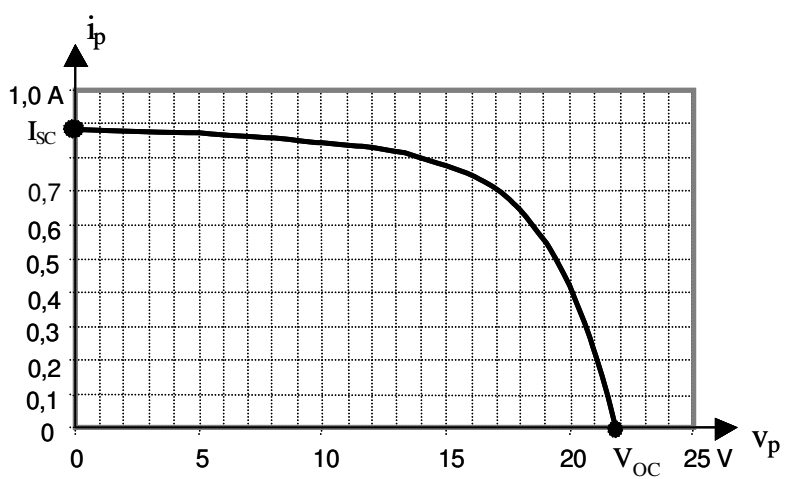

Fig. 2 : I-V characteristic of the A13P amorphous silicon PV made up by free-energy ${ }^{\mathrm{TM}}(\mathrm{a}) \mathrm{1000W} / \mathrm{m}^{2}$

This type of characteristic can be modelled [2] in static mode by an electrical equivalent circuit as shown in Fig 3.

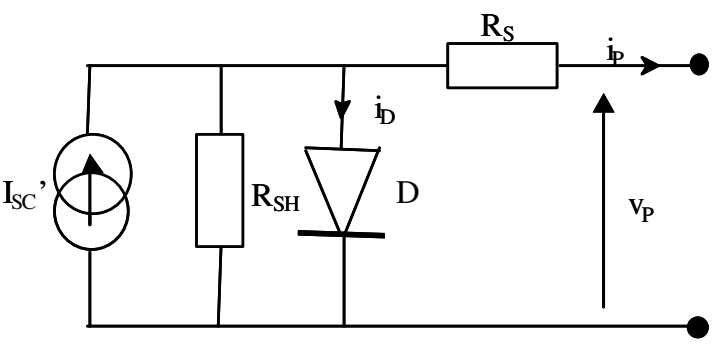

Fig. 3 : Electrical equivalent circuit of a PV

$\mathrm{R}_{\mathrm{S}}, \mathrm{R}_{\mathrm{S}_{\mathrm{H}}}$ : Electrical resistors

D : Equivalent diode checking the Schotkley expression $\mathrm{I}_{\mathrm{SC}}=\frac{\left(\mathrm{R}_{\mathrm{S}}+\mathrm{R}_{\mathrm{SH}}\right)}{\mathrm{R}_{\mathrm{SH}}} \mathrm{I}_{\mathrm{SC}} \approx \mathrm{I}_{\mathrm{SC}}:$ Current sources proportional to the irradiation absorbed by the PV module.

\section{Method of determination of the elements of the electrical equivalent circuit}

The I-V characteristic of a PV presents three particular working areas.

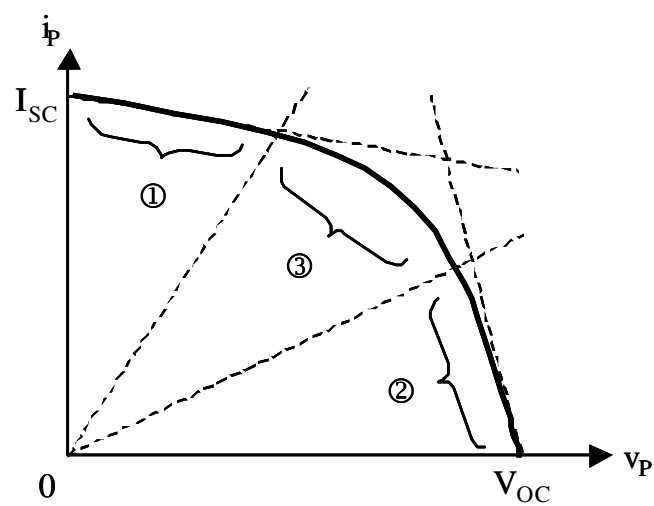

Fig. 4 : The three particular working areas of the IV characteristic

The values of the various elements of the electrical equivalent circuit will be deduced from particular working mode of each area.

\section{A. Analysis of the first area}

In this area an open circuit can replace the equivalent diode D. Indeed its voltage is quite under the threshold voltage. In this case, the electrical equivalent circuit can be assimilated to a current source as shown in Fig. 5 with $\mathrm{R}_{\mathrm{SH}}{ }^{\prime}=\mathrm{R}_{\mathrm{S}}+\mathrm{R}_{\mathrm{SH}} \approx \mathrm{R}_{\mathrm{SH}}$.

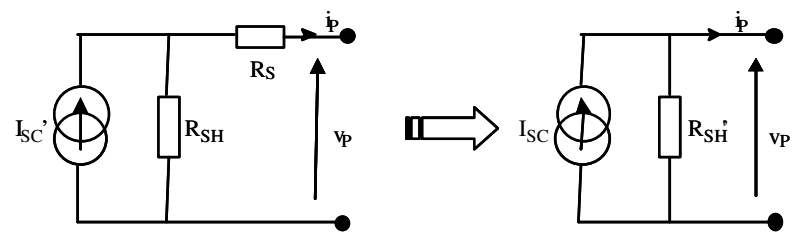

Fig. 5 : Equivalent current source of the working mode of th PV module in the area $n^{\circ} 1$

$\mathrm{R}_{\mathrm{SH}}$ ' is defined by a graphical method as shown in fig6. Its value is directly determineted by the slope of the curve at the $\mathrm{I}_{\mathrm{SC}}$ point.

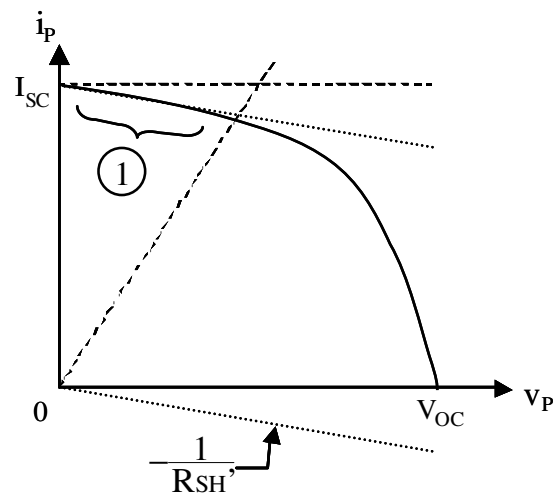

Fig. 6 : Graphical determination of the value of the resistance $\mathbf{R}_{\mathrm{SH}}$

\section{B. Analysis of the second area}

In this area, the terminal voltage for the diode is very important, thus for each working point it can be replaced by a Thévenin equivalent circuit as shown in Fig. 7.

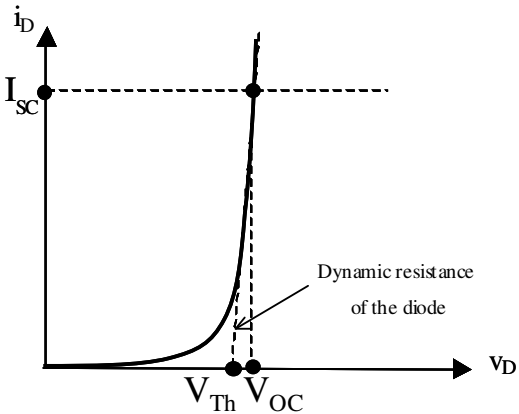

Fig. 7 : I-V characteristic of the diode D

Near the no-load operating point, the $\mathrm{R}_{\mathrm{SH}}$ current can be neglected in comparison to the diode current. Then the diode current is close to the short circuit current as shown in Fig. 8. 


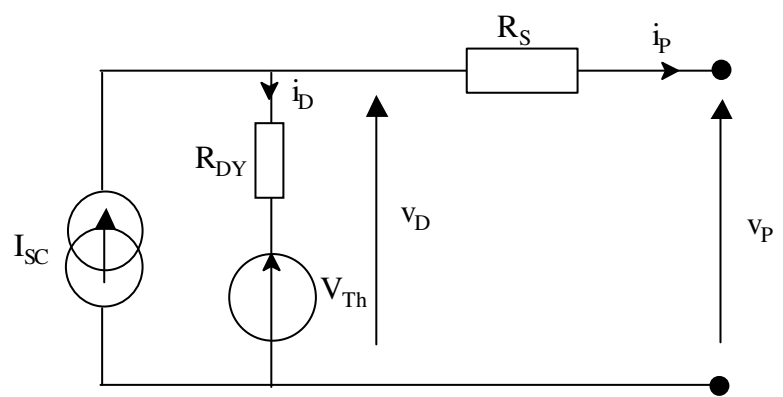

Fig. 8 : Electrical equivalent circuit of a PV module near the no load point

$\mathrm{V}_{\mathrm{Th}}$ : represents the threshold voltage of the diode D. $\mathrm{R}_{\mathrm{DY}}$ :represents the dynamic resistance of the diode The values of $V_{T h}$ and $R_{D Y}$ are function of $I_{S C}$

Hence, in the second area, the electrical equivalent circuit of the PV module behaves like the Thévenin equivalent circuit shown in Fig 9.

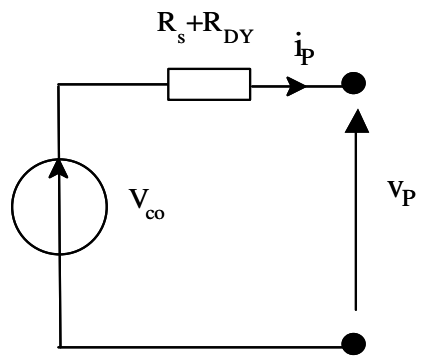

Fig. 9 : Thévenin equivalent circuit of the PV module near the open circuit mode

The Fig 10 shows how to determine graphically the resistors equivalent to $R_{s}+R_{D Y}$.

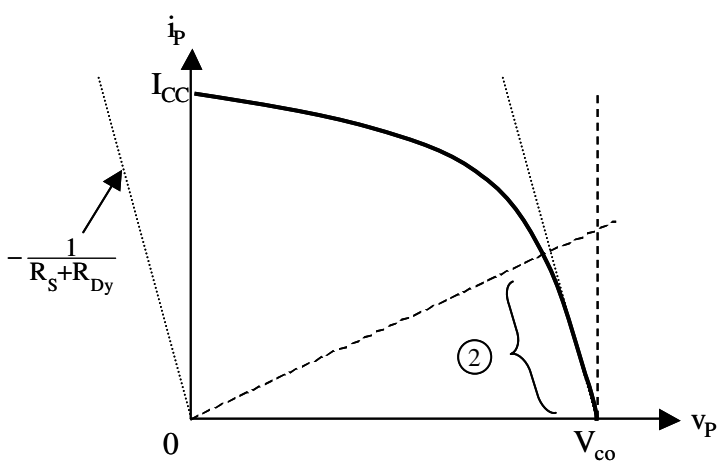

Fig. 10 : Graphical détermination of the resistor equivalent to $\mathbf{R}_{\mathbf{S}}+\mathbf{R}_{\mathbf{D Y}}$

The expression of the resistor $\mathrm{R}_{\mathrm{DY}}$ can be obtained from the Schotkley expression of the diode as well as follow:

$$
I_{D}=n_{p} I_{S}\left(\exp \left(\frac{V_{D}}{n_{s} V_{T}}\right)-1\right)
$$

$\mathrm{V}_{\mathrm{T}}(\mathrm{T})=\mathrm{V}_{\mathrm{T}_{0}} \frac{\mathrm{T}}{\mathrm{T}_{0}}:$ Gap voltage $\left(\mathrm{V}_{\mathrm{T}_{0}}=2610^{-3} \frac{\mathrm{T}_{0}}{300}\right)$

with $\mathrm{I}_{\mathrm{S}}$ : saturation current
In high-level injection mode, the diode equation verifies the inequality:

$$
\exp \left(\frac{V_{D}}{n_{s} V_{T}}\right)>>1
$$

Thus, relation (1) becomes :

$$
\mathrm{V}_{\mathrm{D}} \approx \mathrm{n}_{\mathrm{s}} \mathrm{V}_{\mathrm{T}} \ln \left(\frac{\mathrm{I}_{\mathrm{D}}}{\mathrm{n}_{\mathrm{p}} \mathrm{I}_{\mathrm{S}}}\right)
$$

The expression of dynamic resistance is obtained by deriving the expression (2):

$$
\mathrm{R}_{\mathrm{DY}}\left(\mathrm{I}_{\mathrm{D}}\right)=\frac{\mathrm{dV}_{\mathrm{D}}}{\mathrm{dI}_{\mathrm{D}}} \approx \frac{\mathrm{n}_{\mathrm{s}} \mathrm{V}_{\mathrm{T}}}{\mathrm{I}_{\mathrm{D}}}
$$

Noting that $\mathrm{i}_{\mathrm{D}} \approx \mathrm{I}_{\mathrm{sc}}$ at the operating point, we obtain:

$$
\mathrm{R}_{\mathrm{DY}}\left(\mathrm{I}_{\mathrm{sc}}\right) \approx \frac{\mathrm{n}_{\mathrm{s}} \mathrm{V}_{\mathrm{T}}}{\mathrm{I}_{\mathrm{SC}}}
$$

Hence, the value of the resistor $R_{S}$ is obtained by substituting $R_{D Y}$ from the value calculated in Fig. 10 .

\section{Analysis of the third area}

In this part of the characteristic, the ThéveninNorton parameters of the PV module vary highly with the current. Again, the PV module cannot be assimilated as a voltage source and nor as a current source. Moreover the MPP is located in the knee of the I-V characteristic. Because of the non linearity of the IV characteristic, the MPP is computed by numerical resolution.

\section{Temperature effect}

The experiment shows that the current of saturation increases in an exponential way with the temperature. For silicium diodes, this current doubles approximately every ten degrees. Assuming the saturation current depends of the temperature as given:

$$
\mathrm{Is}(\mathrm{T})=\mathrm{Is}(\mathrm{T} 0) \exp (\mathrm{k} \Delta \mathrm{T})
$$

$$
\left\{\begin{array}{l}
\mathrm{T}_{0}: \text { Reference temperature in degree Kelvin } \\
\Delta \mathrm{T}=\mathrm{T}-\mathrm{T}_{0}: \text { Temperature variation } \\
\mathrm{k}: \text { Empirical value }
\end{array}\right.
$$

Substituting $\mathrm{V}_{\mathrm{T}}$ and $\mathrm{I}_{\mathrm{S}}$ in Eq.(3), by their expressions at varying temperatures, we obtain :

$$
\operatorname{Voc}(\mathrm{T}) \approx \mathrm{n}_{\mathrm{s}} \mathrm{VT}(\mathrm{T} 0) \frac{\mathrm{T}}{\mathrm{T} 0} \ln \left(\frac{\mathrm{IsC}}{\mathrm{n}_{\mathrm{p}} \mathrm{Is}(\mathrm{T}) \exp (\mathrm{k} \Delta \mathrm{T})}\right)
$$

By developing the expression (6) and by introducing the term $\Delta \operatorname{Voc}(\mathrm{T})=\operatorname{Voc}(\mathrm{T})-\operatorname{Voc}(\mathrm{T} 0) \quad\left(\right.$ the $\mathrm{V}_{\mathrm{OC}}$ variation at 
different temperatures to unload operating points ). The relationship of $\mathrm{k}$ is given as:

$$
\mathrm{k}=\frac{\frac{\Delta \mathrm{T}}{\mathrm{T}_{0}} \operatorname{Voc}\left(\mathrm{T}_{0}\right)-\Delta \operatorname{Voc}(\mathrm{T})}{\mathrm{n}_{\mathrm{s}} \mathrm{VT}_{\mathrm{T}}\left(\mathrm{T}_{0}\right) \Delta \mathrm{T}\left(1+\frac{\Delta \mathrm{T}}{\mathrm{T} 0}\right)}
$$

The knowledge of Voc for two operating temperatures is enough to determine the value of $\mathrm{K}$.

\section{Approximate analytical expression of the MPP}

The nature of the equivalent electrical diagram of a PV module leads to an implicit relation between the MPP, terminal voltage and current. Nevertheless it is possible to establish an approximate analytical expression of the MPP deduced from the expressions of $\mathrm{P}_{\mathrm{ms}}$ and $\mathrm{P}_{\mathrm{mt}}$ defined in accordance with the figure (11). " $\mathrm{P}_{\mathrm{ms}}$ " is the power defined by the product of the current and voltage corresponding to the intersection of the characteristics of the equivalent current source and equivalent voltage source. " $\mathrm{P}_{\mathrm{mt}}$ " is the theoretical maximum power of the PV module defined by the product of the two remarkable parameters $\mathrm{I}_{\mathrm{SC}}$ and $\mathrm{V}_{\mathrm{OC}}$.

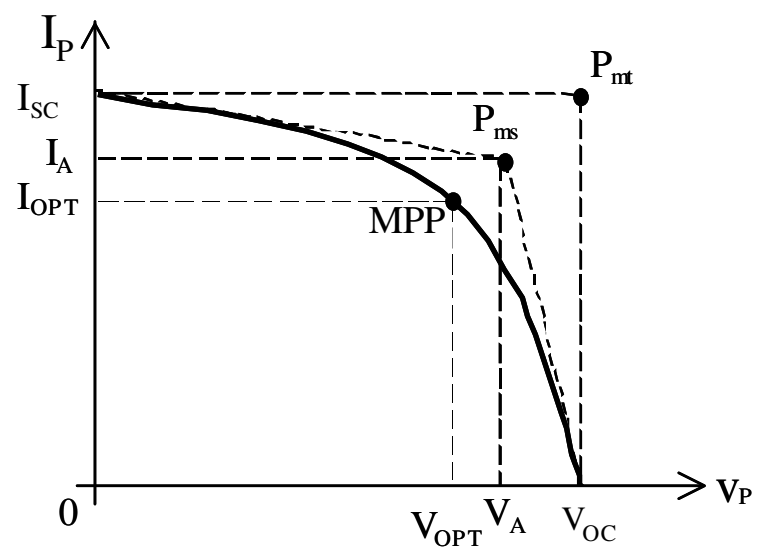

Fig. 11 : Graphical representation of Pms and Pmt

\section{A. Expression of $P_{m s}$ :}

$$
\operatorname{Pms}=\operatorname{Pmt} \frac{\left(1-\frac{\text { RsIsC }}{\text { VoC }}\right)\left(1-\frac{\text { VoC }}{\text { RsHIsC }}\right)}{\left(1-\frac{\text { Rs }}{\text { RsH }}\right)^{2}}
$$

To be more suitable, the terms :

$$
\begin{gathered}
\varepsilon S^{\prime}=\frac{\text { RsISC }^{\prime}}{\text { VOC }} \quad \varepsilon S H=\frac{\text { VOC }}{\text { RsHISC }} \quad \varepsilon_{S H-S}=\varepsilon_{S}{ }^{\prime} \varepsilon_{S H}=\frac{R_{S}{ }^{\prime}}{R_{S H}} \\
\text { with } R_{S}{ }^{\prime} \approx R_{S}+R_{D y}
\end{gathered}
$$

are introduced in the expression (8):

$$
\mathrm{P}_{\mathrm{ms}}=\mathrm{P}_{\mathrm{mt}} \frac{\left(1-\varepsilon_{\mathrm{S}}{ }^{\prime}\right)\left(1-\varepsilon_{\mathrm{SH}}\right)}{\left(1-\varepsilon_{\mathrm{SH}-\mathrm{S}}\right)^{2}}
$$

$\varepsilon_{\mathrm{S}}, \varepsilon_{\mathrm{SH}}, \varepsilon_{\mathrm{SH}-\mathrm{S}}$, Reducing factors. These factors take into account the different kinds of electrical imperfections of the PV module.

Generally the influence of the term $\left(1-\varepsilon_{\mathrm{SH}-\mathrm{S}}\right)^{2}$ can be neglected. In this case the equation (10) becomes:

$$
\mathrm{P}_{\mathrm{ms}} \approx \mathrm{P}_{\mathrm{mt}}\left(1-\varepsilon_{\mathrm{S}}{ }^{\prime}\right)\left(1-\varepsilon_{\mathrm{SH}}\right)
$$

\section{B. MPP expression with no resistive losses}

The calculation of the MPP, without resistive losses, will enable us to introduce a first explicit relation. The MPP with resistive losses will be established starting from this expression.

Without resistive losses, the electrical equivalent circuit of the PV module becomes :

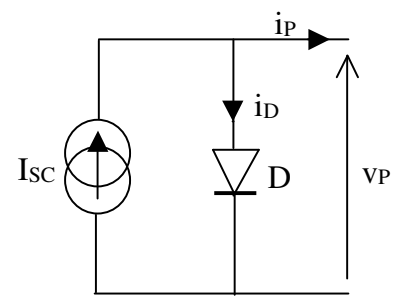

Fig. 12 : Equivalent electrical circuit with no resistive losses

The maximum power point called MPP' is the solution of the equation:

$$
\frac{\mathrm{d}\left(\mathrm{v}_{\mathrm{p}} \mathrm{i}_{\mathrm{P}}\right)}{\mathrm{dv} \mathrm{P}_{\mathrm{P}}}=0
$$

Noting that $\frac{\mathrm{V}_{\mathrm{P}}}{\mathrm{n}_{\mathrm{S}} \mathrm{V}_{\mathrm{T}}}>>1$, the equation (12) yields to the implicit relation given as follows:

$$
\left(\mathrm{n}_{\mathrm{p}} \mathrm{I}_{\mathrm{S}} \exp \left(\frac{\mathrm{V}_{\mathrm{P}}}{\mathrm{n}_{\mathrm{S}} \mathrm{V}_{\mathrm{T}}}\right)\right)\left(\frac{\mathrm{V}_{\mathrm{P}}}{\mathrm{n}_{\mathrm{S}} \mathrm{V}_{\mathrm{T}}}\right) \approx \mathrm{I}_{\mathrm{SC}}
$$

Introducing the parameters:

$$
\mathrm{x}=\frac{\mathrm{I}_{\mathrm{SC}}}{\mathrm{n}_{\mathrm{P}} \mathrm{I}_{\mathrm{S}}} \text { and } \mathrm{y}=\frac{\mathrm{V}_{\mathrm{P}}}{\mathrm{n}_{\mathrm{S}} \mathrm{V}_{\mathrm{T}}}
$$

and applying the logarithmic function from the two parts of the relation (13), it becomes :

$$
\operatorname{Ln}(\mathrm{x})=\mathrm{y}+\operatorname{Ln}(\mathrm{y})
$$

Or, the terminal voltage of a diode is confined between the two values $0,6 \mathrm{~V}$ et $0,7 \mathrm{~V}$, then the terminal voltage $\mathrm{V}_{\mathrm{p}}$ evolves in the interval:

$$
0,6 \mathrm{n}_{\mathrm{s}}<\mathrm{V}_{\mathrm{p}}<0,7 \mathrm{n}_{\mathrm{s}}
$$

Noting that $\mathrm{V}_{\mathrm{T}}$ remains nearly from the value of $\mathrm{V}_{\mathrm{TO}}$ and substituting the expression (16) in the expression (14) leads to y to the interval: 


\section{$3,14<\operatorname{Ln}(y)<3,30$}

The logarithmic values of $y$ are very near from each other. By replacing $\operatorname{Ln}(\mathrm{y})$ by its geometric average:

$$
\operatorname{Ln}(y) \approx \operatorname{Ln}(\sqrt{27.23)} \approx \operatorname{Ln}(25)
$$

an explicit expression of the equation (15) can be done:

$$
\mathrm{y}=\operatorname{Ln}\left(\frac{\mathrm{x}}{25}\right)
$$

Introducing (14) in (15), the approximate analytical expression of the voltage corresponding to the MPP' is given as:

$$
\mathrm{V}_{\mathrm{p}} \approx \mathrm{n}_{\mathrm{s}} \mathrm{V}_{\mathrm{T}} \operatorname{Ln}\left(\frac{\mathrm{ISC}}{25 \mathrm{n}_{\mathrm{p}} \mathrm{Is}_{\mathrm{s}}}\right)
$$

In resolving the equation (2) by introducing the equation (18), the current corresponding to the MPP' can be written as.

$$
\mathrm{I} \approx \approx \frac{24}{25} \mathrm{IsC}
$$

Finally, an approximate explicit analytical expression of the MPP' can be established from the product of the equation (18) and the equation (19):

$$
\mathrm{MPP}^{\prime} \approx 0,96 \mathrm{n}_{\mathrm{s}} \mathrm{V}_{\mathrm{T}} \mathrm{I}_{\mathrm{SC}} \operatorname{Ln}\left(\frac{\mathrm{I}_{\mathrm{SC}}}{25 \mathrm{n}_{\mathrm{p}} \mathrm{I}_{\mathrm{S}}}\right)
$$

\section{MPP expression with resistive losses:}

As it is shown in fig 13, the resistive losses are at the origin of the crashing of the I-V characteristic.

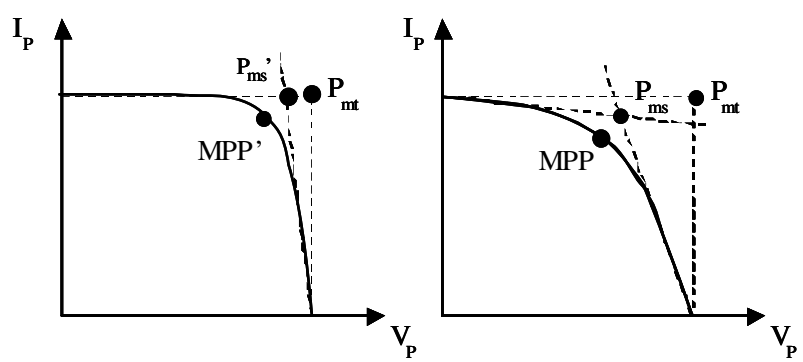

Fig. 13 : I-V characteristic without and with resistive losses

By making the assumption that the I-V characteristics, without and with resistive losses present a homothety on the powers, we can write that :

$$
\mathrm{MPP} \approx \frac{\mathrm{Pms}}{\mathrm{Pms}}, \mathrm{MPP}
$$

where, $\mathrm{P}_{\mathrm{ms}}$ ' power is defined in accordance with the figure (13). Without resistive losses, the slope of the characteristic at the open circuit voltage is inversely proportional to the dynamic resistance of the equivalent diode, which gives us:

$$
\mathrm{P}_{\mathrm{ms}}^{\prime}=\left(\mathrm{V}_{\mathrm{OC}}-\mathrm{R}_{\mathrm{DY}} \mathrm{I}_{\mathrm{SC}}\right) \mathrm{I}_{\mathrm{SC}}
$$

By substituting the expression of $\mathrm{R}_{\mathrm{DY}}$ from the equation (4) and introducing the theoretical maximum power Pmt in the equation (22) leads to:

$$
\mathrm{P}_{\mathrm{ms}}^{\prime}=\mathrm{P}_{\mathrm{mt}}\left(1-\frac{\mathrm{n}_{\mathrm{S}} \mathrm{V}_{\mathrm{T}}}{\mathrm{V}_{\mathrm{OC}}}\right)
$$

Replacing $\mathrm{P}_{\mathrm{ms}}$ by the expression (11) and $\mathrm{P}_{\mathrm{ms}}$, by the expression (23), we get :

$$
\frac{\mathrm{P}_{\mathrm{ms}}}{\mathrm{P}_{\mathrm{ms}}} \approx \frac{\left(1-\varepsilon_{\mathrm{S}}\right)\left(1-\varepsilon_{\mathrm{SH}}\right)}{1-\frac{\mathrm{n}_{\mathrm{S}} \mathrm{V}_{\mathrm{T}}}{\mathrm{V}_{\mathrm{OC}}}}
$$

Noting that $\frac{\mathrm{nsVT}}{\mathrm{VOC}} \ll 1$, the ratio becomes :

$$
\frac{\mathrm{P}_{\mathrm{ms}}}{\mathrm{P}_{\mathrm{ms}}} \approx\left(1-\varepsilon_{\mathrm{S}}\right)\left(1-\varepsilon_{\mathrm{SH}}\right)\left(1+\frac{\mathrm{n}_{\mathrm{S}} \mathrm{V}_{\mathrm{T}}}{\mathrm{V}_{\mathrm{OC}}}\right)
$$

Noting that the term $\varepsilon s^{\prime} \frac{\mathrm{ns} V \mathrm{~T}}{\mathrm{VOC}}$ can be neglected, and by introducing the parameter $\varepsilon_{\mathrm{S}}$ defined as :

$$
\varepsilon_{\mathrm{S}}=\varepsilon_{\mathrm{S}}-\frac{\mathrm{n}_{\mathrm{S}} \mathrm{V}_{\mathrm{T}}}{\mathrm{V}_{\mathrm{OC}}}
$$

We obtain a simplified expression of the ratio (25):

$$
\frac{\mathrm{P}_{\mathrm{ms}}}{\mathrm{P}_{\mathrm{ms}}} \approx\left(1-\varepsilon_{\mathrm{S}}\right)\left(1-\varepsilon_{\mathrm{SH}}\right)
$$

Finally Eq. (20), (21) and (27), leads to the approximate analytical expression of the MPP:

$$
\mathrm{MPP} \approx 0,96 . n_{\mathrm{s}} \mathrm{V}_{\mathrm{T}} \mathrm{I}_{\mathrm{SC}} \operatorname{Ln}\left(\frac{\mathrm{I}_{\mathrm{SC}}}{25 \mathrm{n}_{\mathrm{p}} \mathrm{I}_{\mathrm{S}}}\right)\left(1-\varepsilon_{\mathrm{S}}\right)\left(1-\varepsilon_{\mathrm{SH}}\right)
$$

To be more convenience, the MPP can be explained in function of the theoretical maximum power.

$$
\left.\mathrm{MPP} \approx 0,96 . \mathrm{P}_{\mathrm{mt}} \frac{\mathrm{n}_{\mathrm{S}} \mathrm{V}_{\mathrm{T}}}{\mathrm{V}_{\mathrm{OC}}} \operatorname{Ln}\left(\frac{\mathrm{I}_{\mathrm{SC}}}{\mathrm{n}_{\mathrm{P}} \mathrm{I}_{\mathrm{S}}}\right) \frac{\operatorname{Ln}(25)}{\operatorname{Ln}\left(\frac{\mathrm{I}_{\mathrm{SC}}}{\mathrm{n}_{\mathrm{P}} \mathrm{I}_{\mathrm{S}}}\right)}\right)\left(1-\varepsilon_{\mathrm{S}}\right)\left(1-\varepsilon_{\mathrm{SH}}\right)
$$

By replacing in the equation (29), the open circuit voltage by the expression deduced from the expression (2):

$$
\mathrm{V}_{\mathrm{oc}} \approx \mathrm{n}_{\mathrm{s}} \mathrm{V}_{\mathrm{T}} \ln \left(\frac{\mathrm{I}_{\mathrm{SC}}}{\mathrm{n}_{\mathrm{p}} \mathrm{I}_{\mathrm{S}}}\right)
$$

We obtain a more elegant formulation of the MPP:

$$
\mathrm{MPP} \approx 0,96 . \mathrm{Pmt}\left(1-\frac{\mathrm{Ln} 25}{\mathrm{Ln} \frac{\mathrm{ISC}}{\mathrm{nPIS}}}\right)(1-\varepsilon \mathrm{s})(1-\varepsilon \mathrm{SH})
$$

As we can see, in this formulation, appear three characteristics reducing factors:

$$
\mathrm{K}_{1}=0,96\left(1-\frac{\mathrm{Ln} 25}{\mathrm{Ln} \frac{\mathrm{ISC}}{\mathrm{nPIS}}}\right) \quad \mathrm{K}_{2}=1-\varepsilon \mathrm{S} \quad \mathrm{K}_{3}=1-\varepsilon_{\mathrm{SH}}
$$

Finally, the maximal power point can be expressed by the simple relationship:

$$
\mathrm{MPP}=\mathrm{K}_{1} \mathrm{~K}_{2} \mathrm{~K}_{3} \mathrm{Pmt}
$$


Where:

$\mathrm{K}_{1}$ is the coefficient of junction characterized by the parameters of Schockley.

$\mathrm{K}_{2}$ is the coefficient characterizing the ohmic falls in the external semiconductor and contacts.

$\mathrm{K}_{3}$ is the coefficient characterizing the escapes due to the microphone and macro foreign material inclusions to the semiconductor.

\section{Fill Factor $(F F)$}

The manufacturers often give the fill factor (FF) which can easily be deduced from the expression (33) of the MPP :

$$
\mathrm{FF}=\frac{\mathrm{MPP}}{\mathrm{P}_{\mathrm{mt}}}=\mathrm{K}_{1} \mathrm{~K}_{2} \mathrm{~K}_{3}
$$

According to the factor $\mathrm{K}_{1}$, The theoretical maximum FF value will always be under 0,96 .

\section{Numerical applications}

\section{A. Electrical circuit parameter calculation}

In what follows, we drew up the equivalent electric diagrams of panels $\mathrm{A} 13 \mathrm{P}$ and $\mathrm{A} 115 \mathrm{P}$ made up by the company Free Energy Europe TM [5]. The I-V characteristics at $25^{\circ} \mathrm{C}$ are given in Fig. 14 under 3 irradiations $\left(250,500\right.$ and $\left.1000 \mathrm{~W} / \mathrm{m}^{2}\right)$.

The table of the figure $n^{\circ} 15$ gives the values of the various elements of the equivalent electric diagram calculated in accordance with the formulas established in the third paragraph.

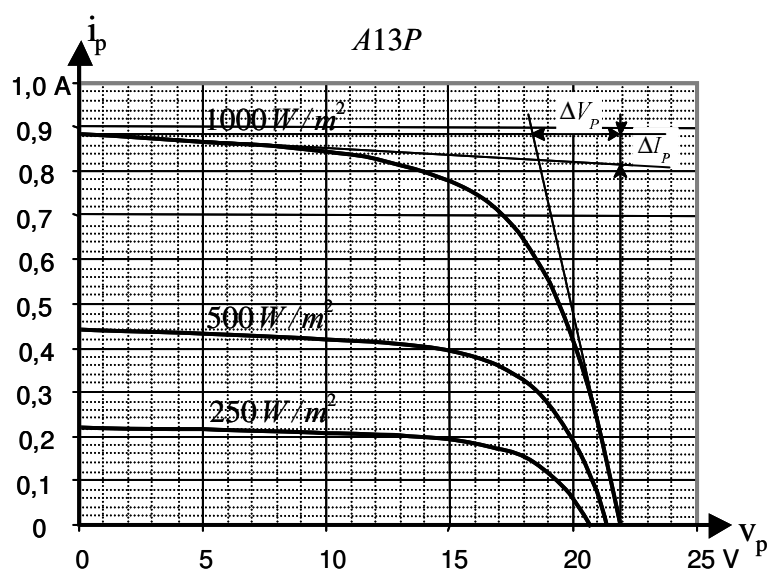

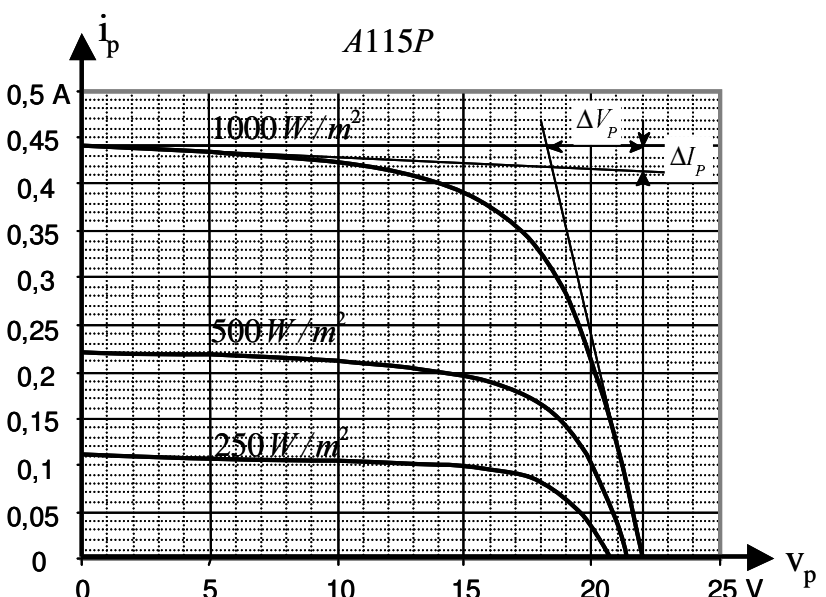

Fig. 14 : I-V characteristic $@ 25^{\circ} \mathrm{C}-\mathrm{A13P}$ and A115P made up by free-energy.

\begin{tabular}{|c|c|c|}
\hline Electrical parameters & $\mathrm{A} 115 \mathrm{P}$ & $\mathrm{A} 13 \mathrm{P}$ \\
\hline $\mathrm{RsH}=\frac{\mathrm{VOC}}{\Delta \mathrm{IP}}$ & $\mathrm{RsH}=\frac{22}{0.034} \approx 650 \Omega$ & $\mathrm{RsH}=\frac{22.1}{0.034} \approx 260 \Omega$ \\
\hline $\mathrm{Is}=\frac{\mathrm{IsC}}{\mathrm{nPexp}\left(\frac{\mathrm{VOC}}{\mathrm{nsVT}}\right)}$ & $\mathrm{Is}=\frac{0.44}{\exp \left(\frac{22}{30 * 26.10^{-3}}\right)} \approx 2.5 .10^{-13} \mathrm{~A}$ & $\mathrm{Is}=\frac{0.89}{\exp \left(\frac{22.1}{30 * 26.10^{-3}}\right)} \approx 4.4 .10^{-13} \mathrm{~A}$ \\
\hline $\mathrm{RDY}=\frac{\mathrm{nsVT}}{\mathrm{IsC}}$ & $\mathrm{RDY}=\frac{30 * 26.10^{-3}}{0.44} \approx 1.8 \Omega$ & $\mathrm{RDY}=\frac{30 * 26.10^{-3}}{0.89} \approx 0.9 \Omega$ \\
\hline $\mathrm{Rs}=\frac{\Delta \mathrm{VP}_{\mathrm{ISC}}}{\mathrm{ISD}} \mathrm{RDY}$ & $\mathrm{Rs}=\frac{3.8}{0.44}-1.8 \approx 6.8 \Omega$ & $\mathrm{Rs}=\frac{4.1}{0.89}-0.9 \approx 3.7 \Omega$ \\
\hline
\end{tabular}

fig $n^{\circ} 15$ : Electrical circuit parameter values of A13P and A115P Panels.

The figure $\mathrm{n}^{\circ} 16$ shows the comparison between the I-V characteristics plot from the equivalent electric circuit (in full lines) and the experimental characteristics (in dotted lines). The curves take very similar forms. However, we notice a more marked divergence toward the knee. Indeed, near this area the equation (1) of the behaviour of the diode is less rigorous. This equation doesn't take into account the conduction currents due to the minority carriers. Its can be solved by introducing in the equivalent electrical circuit an additionnal diode connected in parallel with the first one. A second solution consists to correct the term $\mathrm{V}_{\mathrm{T}}$ by an empirical coefficient $\lambda$ (called ideality factor) close to 2 near the MPP operating point. Indeed, in this area the diode work in less-injection. This coefficient remains difficult to determinate because it doesn't vary linearly versus temperature and current. 
A115P
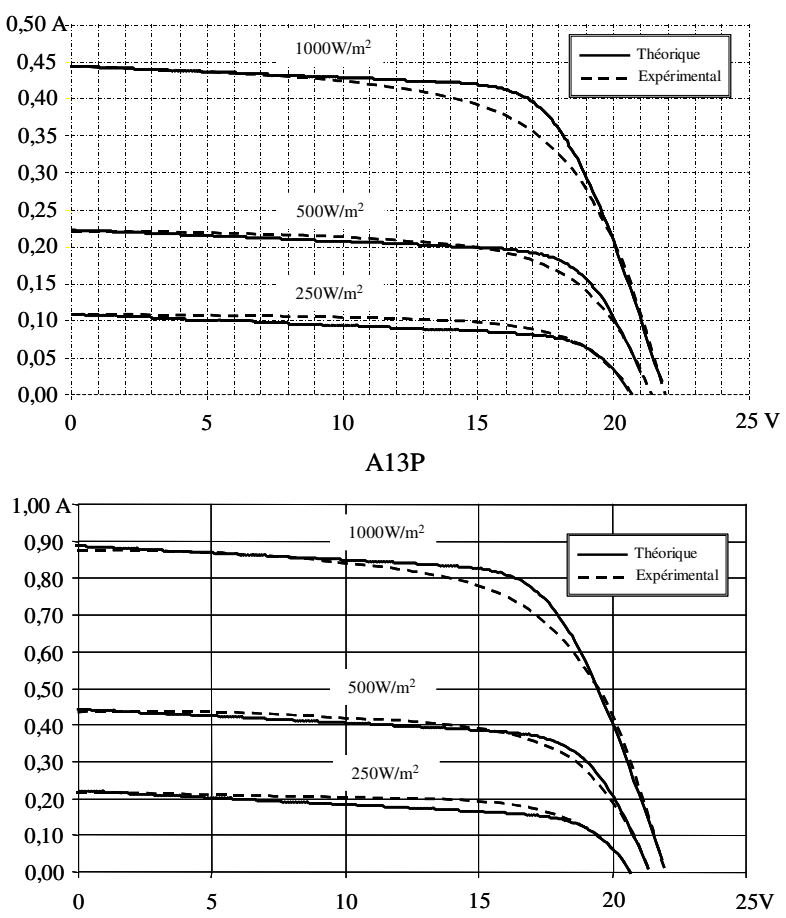

Fig. 16 : Comparison of the theoretical and experimental characteristics of the A13P and A115P@ $25^{\circ} \mathrm{C}$.

\section{B. Temperature effect}

The table in Fig. 17 gives the value of the coefficient K calculated for the characteristics shown in figure 18 with the formula (7).

A13P / A115P

\begin{tabular}{|c|c|c|c|c|c|c|c|}
\hline $\mathrm{T}_{0}$ & $\mathrm{~T}$ & $\mathrm{~V}_{\mathrm{OC}}\left(\mathrm{T}_{0}\right)$ & $\mathrm{V}_{\mathrm{OC}}(\mathrm{T})$ & $\Delta \mathrm{V}_{\mathrm{OC}}(\mathrm{T})$ & $\Delta \mathrm{T}$ & $\mathrm{n}_{\mathrm{S}} \mathrm{V}_{\mathrm{T}}\left(\mathrm{T}_{0}\right)$ & $\mathrm{K}$ \\
\hline $298 \mathrm{~K}$ & $323^{\circ} \mathrm{K}$ & $22 \mathrm{~V}$ & $20 \mathrm{~V}$ & $-2 \mathrm{~V}$ & $25^{\circ} \mathrm{K}$ & $0,78 \mathrm{~V}$ & $\mathbf{0 . 1 8}$ \\
\hline
\end{tabular}

Fig $n^{\circ} 17$ : Table of the calculation of the coefficients $K$ of the PV module.

The curves of figure 18 represents the experimental characteristics (in dotted lines) and theoretical (in full lines) of $\mathrm{i}_{\mathrm{P}}-\mathrm{v}_{\mathrm{P}}$ under an irradiation of $1000 \mathrm{~W} / \mathrm{m}^{2}$ of $\mathrm{A} 13 \mathrm{P}$ and $\mathrm{A} 115 \mathrm{P} \mathrm{PV}$ module for 3 temperatures $\left(5^{\circ} \mathrm{C}, 25^{\circ} \mathrm{C}\right.$ and $50^{\circ} \mathrm{C}$ ). In the area (2), we notice a good accuracy between the two kinds of curves.

The variation of the short circuit current in versus temperature remaining small, it is not taken into account in the model developed in this article.

In the area (3) where MPP is located, the variation stays sensibly constant for the 3 temperatures and it's the case for both PV modules.
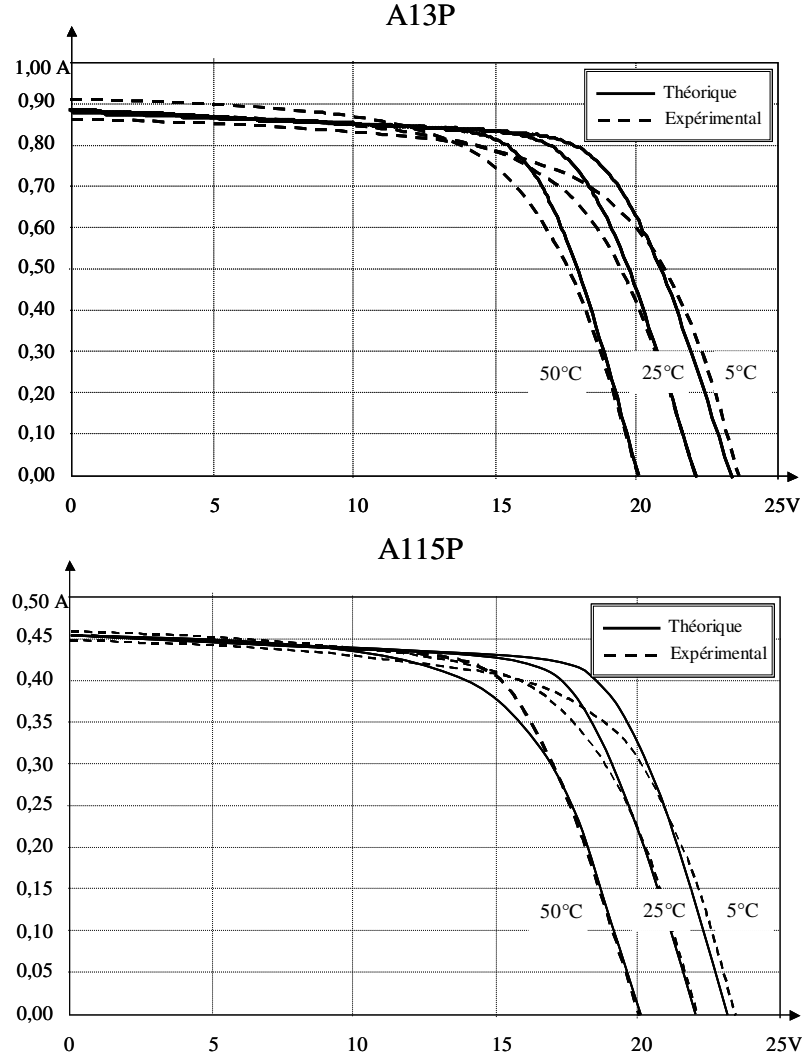

Fig. 18 : IV characteristic in function of the temperature

\section{C. $M P P$}

Table $\mathrm{n}^{\circ} 19$ gives the values of the three reducing factors defined as equations (32). A comparison of the maximal power point between experimental values and theoretical values calculated from the expression (31) is presented.

\begin{tabular}{|c|c|c|c|c|c|c|}
\hline & $\mathrm{K}_{1}$ & $\mathrm{~K}_{2}$ & $\mathrm{~K}_{3}$ & $\begin{array}{c}\text { MPP } \\
\text { Practical }\end{array}$ & $\begin{array}{c}\text { MPP } \\
\text { Theoretical }\end{array}$ & $\begin{array}{c}\text { Difference } \\
(\%)\end{array}$ \\
\hline $\begin{array}{c}\mathrm{A} 115 \mathrm{P} \\
1000 \mathrm{~W} / \mathrm{m}^{2}\end{array}$ & 0.8504 & 0.864 & 0.9231 & $5.841 \mathrm{~W}$ & $6.565 \mathrm{~W}$ & $+12.4 \%$ \\
\hline $\begin{array}{c}\mathrm{A} 115 \mathrm{P} \\
500 \mathrm{~W} / \mathrm{m}^{2}\end{array}$ & 0.8476 & 0.9301 & 0.851 & $3.15 \mathrm{~W}$ & $3.143 \mathrm{~W}$ & $-0.21 \%$ \\
\hline $\begin{array}{c}\mathrm{A} 115 \mathrm{P} \\
250 \mathrm{~W} / \mathrm{m}^{2}\end{array}$ & 0.8447 & 0.9636 & 0.6923 & $1.365 \mathrm{~W}$ & $1.326 \mathrm{~W}$ & $-2.83 \%$ \\
\hline $\begin{array}{c}\mathrm{A} 13 \mathrm{P} \\
1000 \mathrm{~W} / \mathrm{m}^{2}\end{array}$ & 0.851 & 0.852 & 0.904 & $12.06 \mathrm{~W}$ & $12.68 \mathrm{~W}$ & $+5.2 \%$ \\
\hline $\begin{array}{c}\mathrm{A} 13 \mathrm{P} \\
500 \mathrm{~W} / \mathrm{m}^{2}\end{array}$ & 0.848 & 0.924 & 0.814 & $6.1 \mathrm{~W}$ & $5.977 \mathrm{~W}$ & $-2 \%$ \\
\hline $\begin{array}{c}\mathrm{A} 13 \mathrm{P} \\
250 \mathrm{~W} / \mathrm{m}^{2}\end{array}$ & 0.845 & 0.9604 & 0.643 & $3.05 \mathrm{~W}$ & $2.34 \mathrm{~W}$ & $-23 \%$ \\
\hline
\end{tabular}

Fig. 19 : Table of the calculation of the coefficients $K_{1}, K_{2}, K_{3}$ and the MPP.

Although, theoretical curves are the less accurate in the area where the MPP point is localised, the result computed by the formula (31) presents very good accuracy in high irradiation. This can be explained by the fact that the theoretical formulation is based on the calculation of a ratio of power, which takes into account the eccentricity of the curves in a better way. 


\section{Conclusion}

In this article, a simple graphic method to determine the elements of the electrical equivalent diagram was presented. This method takes into account the influence of the temperature. The I-V characteristics of PV module computed from the elements of the electrical diagram were compared to experimental curves in different conditions of irradiation and temperature. The theoretical curves are conformed to the experimental characteristic; however, a noticeable divergence can be observed in the knees of the curves. To get a better accuracy, a model 2-diodes whose parameters are obtained by numerical approach must be used as proposed in [7]. An original method to establish the analytical expression of the maximal power point was presented. The proposed expression enables to obtain a better accuracy value compared to these computed from the electrical equivalent 1 diode diagram.

\section{Acknowledgements}

The authors makes a point of thanking Mr Guillardeau the plant manager of the company Free Energy Europe ( LensFrance) for his experimental data which enabled us to complete this work of modelling.

\section{References}

[1] IKEGAMI T., MAEZONO T. , NAKANISHI F. YAMAGATA Y., EBIHARA K., Estimation of equivalent circuits parameters of PV module and ist application to optimal operation of PV system', Solar Energy Materials \& Solar Cells 67 (2001) pp389-395. ELSEVIER

[2] BURESCH M., Photovoltaic Energy Systems - Design and Installation, McGraw-Hill, New-York, 1983.

[3] RADZIEMSKA E., KLUGMANN E.,'Thermally affected parameters of the current-voltage characteristics of silicon photocell', Energy Conversion and Management 43 (2002) pp 1889-1900. PERGAMON.

[4] 'Effect of illumination intensity and temperature on the I-V characteristics of n-C/P-Si heterojunction', Solar Energy Materials \& Solar Cells 73 (2002), pp261-267. ELSEVIER.

[5] www.free-energy.net

[6] STIRN RJ., Junction characteristics of a silicon solar cells. In : $9^{\text {th }}$ IEEE Photovoltaic Specialists Conference, 1972, pp 72-82.

[7] STUTENBAUEUMER U., BELAYNEH M., 'Equivalent model of monocrystalline, polycrystalline and amorphous silicon solar cells', Renewable Energy 18 (1999), pp 501-512. PERGAMON. 